\title{
Re-description of Daphnia (Ctenodaphnia) from lakes in the Khumbu Region, Nepalese Himalayas, with the erection of a new species, Daphnia himalaya, and a note on an intersex individual
}

\author{
Marina MANCA, ${ }^{*}$ Patrick MARTIN, ${ }^{1)}$ Dinora Carolina PEÑALVA-ARANA ${ }^{2)}$ and John A.H. BENZIE ${ }^{3)}$ \\ CNR Institute of Ecosystem Study, Largo Tonolli 52, 28922 Verbania Pallanza, Italy \\ ${ }^{1)}$ Department of Biology, University of York, Y010 5NB, York, UK \\ ${ }^{2)}$ Great Lakes Water Institute, UW-Milwaukee, Milwaukee, WI 53204 USA \\ ${ }^{3)}$ Plant Systems Biology, Vlanders Interuniversity Institute for Biotechnology, Technologiepark, Ghent, Belgium \\ *e-mail corresponding author: m.manca@ise.cnr.it
}

\begin{abstract}
We present here a detailed description of Ctenodaphnia-type Daphnia specimens collected from lakes in the Nepalese Himalayas between 1994 and 2004, including mature females and adult males. The specimens examined share certain diagnostic traits with Daphnia tibetana (Sars 1903), and others with Daphnia fusca (Gurney 1906). A re-appraisal of their previous synonymy with D. fusca and a comparison with all published descriptions of similar species from the region indicate that they represent a new species named here as Daphnia himalaya. The chance discovery of a sex intergrade of the same species allowed a description of the secondary sexual characteristics in this interesting and rare intermediate state to be reported, and its possible ecological implications to be discussed, as well.
\end{abstract}

Key words: Cladocera, Daphnia, taxonomy, Himalayas, sex intergrade

\section{INTRODUCTION}

Daphnia is an important member of pond and lake systems in the Himalayas and Tibet (Sars 1903; Rylov 1930; Wagler 1936; Hutchinson 1937). The taxonomy of the melanic Ctenodaphnia from this region is problematical, largely because incomplete descriptions have been published to date. Originally, three species were identified: Daphnia pamirensis (Rylov 1930), Daphnia fusca (Gurney 1906) and Daphnia tibetana (first described as Daphniopsis tibetana, Sars 1903). These species have been synonymized in every pairwise combination, or all three fused in one species, over the last century (Wagler 1936; Brehm \& Woltereck 1939). Most recently, Benzie (2005) synonymized the genus Daphniopsis with the genus Daphnia, and D. pamirensis with D. fusca. He also synonymized Daphnia specimens from the Khumbu Region in Tibet, identified as $D$. tibetana by Manca et al. (1994), with D. fusca. This decision was based on differences in the characteristics in the outline drawings and notes in that paper from other descriptions of D. tibetana (Sars 1903; Chiang \& Du 1979; Hann 1986) and similarities with D. fusca. Subsequently, Zhao \& Wang (2005), using specimens from Tibet, differentiated two species on the basis of their having a tail spine or not, as being Daphniopsis tibetana (no tail spine) and Daphnia tibetana (with a tail spine), but the description of their males differed from that of Chiang \& Du (1979).

It is clear that more detailed reports of the material from the Khumbu Region will assist the resolution of the taxonomy of this important group. Samples from the Khumbu Region provided the only data on males and ephippial females for $D$. fusca after their synonymy by Benzie (2005). The characters then used to further differentiate D. fusca from D. tibetana (Benzie 2005) depend critically on the details of the morphology of specimens from this region. The region has been the subject of extensive limnological research following a scientific expedition in 1964. The first data on the morphometry, temperature, chemistry and biology of lakes in the Khumbu Region were published by Löffler (1969). He reported large, darkly pigmented $D$. tibetana from only clear lakes and littoral zones, a distribution previously suggested by Hutchinson (1937). Subsequently, within the framework of the Ev-K2-CNR Project on the long-distance transport of micro-pollutants, a total of 48 lakes were visited in the Khumbu Region of the Nepalese Himalayas between 1994 and 2004 providing sound ecological and distributional data (Lami et al. 2006). Clarification of the status of these populations will help define the status of other species in the region.

A re-examination of specimens from the populations of $D$. tibetana reported by Manca et al. (1994), and considered to be D. fusca by Benzie (2005), has demonstrated they have some characteristics in common with each of these taxa, but others that clearly differentiate them from both these species. This paper re-describes the Khumbu specimens in detail and nominates a new species name for these populations. In addition, a sex intergrade (sensu Banta 1939; intersex according to Mitchell 2001) found in one of the samples, is described and discussed. 


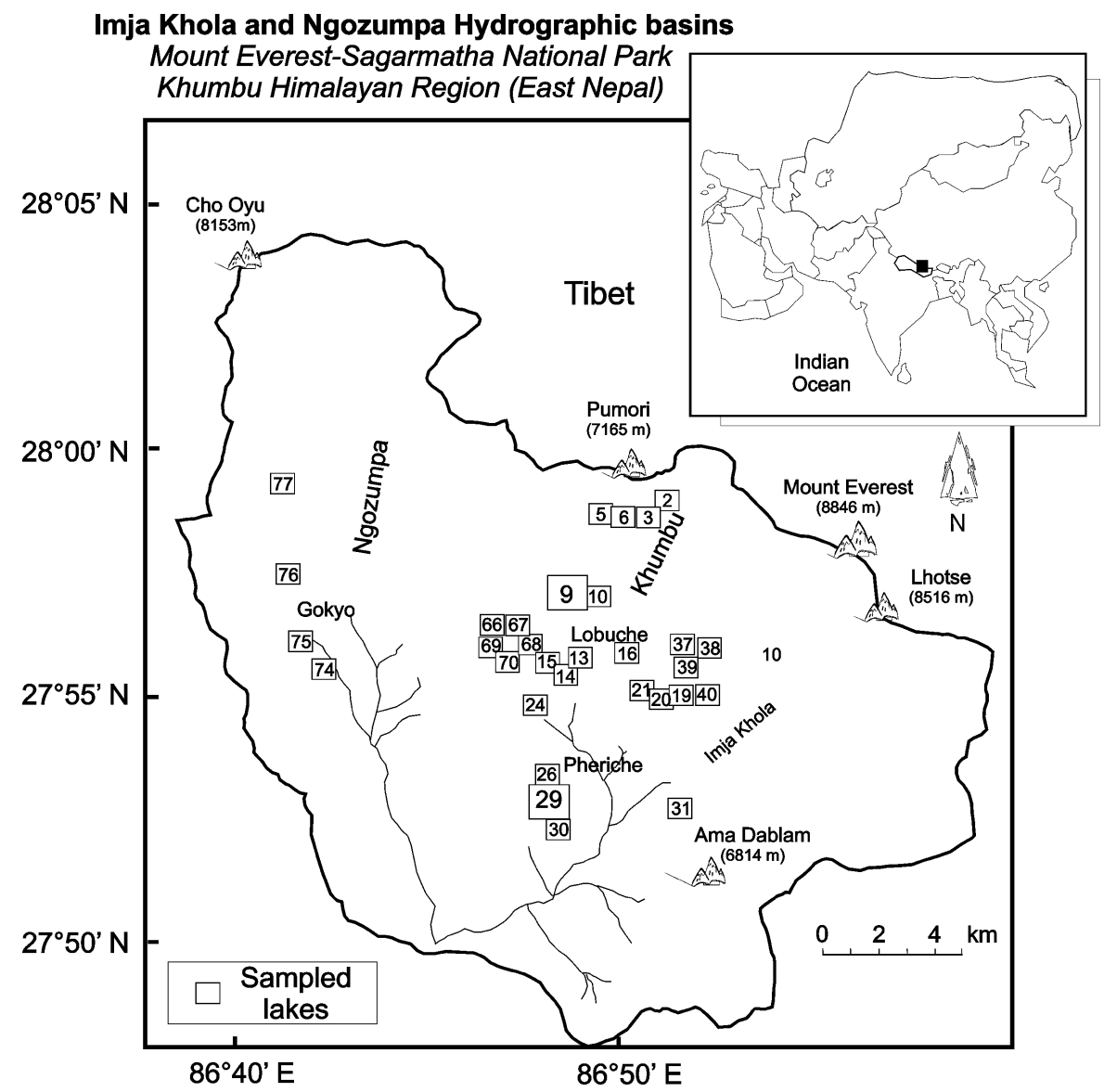

Fig. 1. Map of Nepal showing sampling locations' cadastre numbers: large squares refer to Daphnia himalaya type localities (from: Manca \& Comoli 2004 modified).

\section{METHODS}

\subsection{Sampling and preparation of specimens}

Thirty one of the 48 lakes included in the Ev-K2CNR Project, a collaborative research program developed between the Italian Research Council and the Royal Nepal Academy of Science and Technology, were sampled for water chemistry, plankton and benthos, mostly on single occasions from the shore by retrieving bottles or plankton nets (126 $\mu \mathrm{m}$ mesh size) thrown by hand or, when possible, from a rubber boat using vertical hauls. Logistic and technical support during sampling was given by a laboratory, called Pyramid, at $5050 \mathrm{~m}$ a.s.1. (http://www.evk2cnr.org/en/). The lakes are situated in the watersheds of the Imja Khola and Ngozumpa, between latitudes N 27 $48^{\prime}$ and $28^{\circ} 05^{\prime}$ and longitudes E $86^{\circ} 39^{\prime}$ and $86^{\circ} 59^{\prime}$ (Fig. 1). All the lakes are situated between 4460 and $5645 \mathrm{~m}$ a.s.l., with an altitude distribution showing a maximum frequency between 5100 and $5300 \mathrm{~m}$. Specimens were preserved in buffered $10 \%$ formalin or $95 \%$ ethanol and examined in 2006 using a Zeiss light microscope at magnifications between $20 \times$ and $100 \times$. Moreover, some individuals were selected for SEM analysis. These were dehydrated in an ethanol series and critical point dried
(BALZERS CPD 010) and imaged using a LEO 435 VP.

The specimens on which the present descriptions are based were found in Lakes CDN9 and CDN29 (the former previously Lake 11 in Löffler 1968, 1969).

\section{RESULTS}

\subsection{Description of specimens}

Type locality: lakes CDN9 (latitude N 2757'54" longitude E $86^{\circ} 48^{\prime} 40^{\prime \prime}$, altitude $5213 \mathrm{~m}$ a.s.1.) and CDN29 (latitude N 2753'26" longitude E 8647'46", altitude $5172 \mathrm{~m}$ a.s.1.). Both lakes have a relatively low ionic content and are at present oligotrophic (Tartari et al. 1998), the former having been so for the last $c a 100$ years (Guilizzoni et al. 1998).

Types: type and paratype specimens have been deposited in the collections of CNR ISE, Verbania, Italy. Holotype: parthenogenetic female, stored in alcohol from sample reference number L29/9/97/6 (photo reference number L29/F25/1). Allotype: Adult male, two individuals dissected, mounted on slides, reference number L9/10/94/2 (photos reference numbers L9/M1/1-4; L9/M2/1-5) and L9/10/94/3. Paratypes: 5 ovigerous females, mounted on slides, reference numbers L29/9/97/1-5 (photos reference numbers L29/F1/1, 

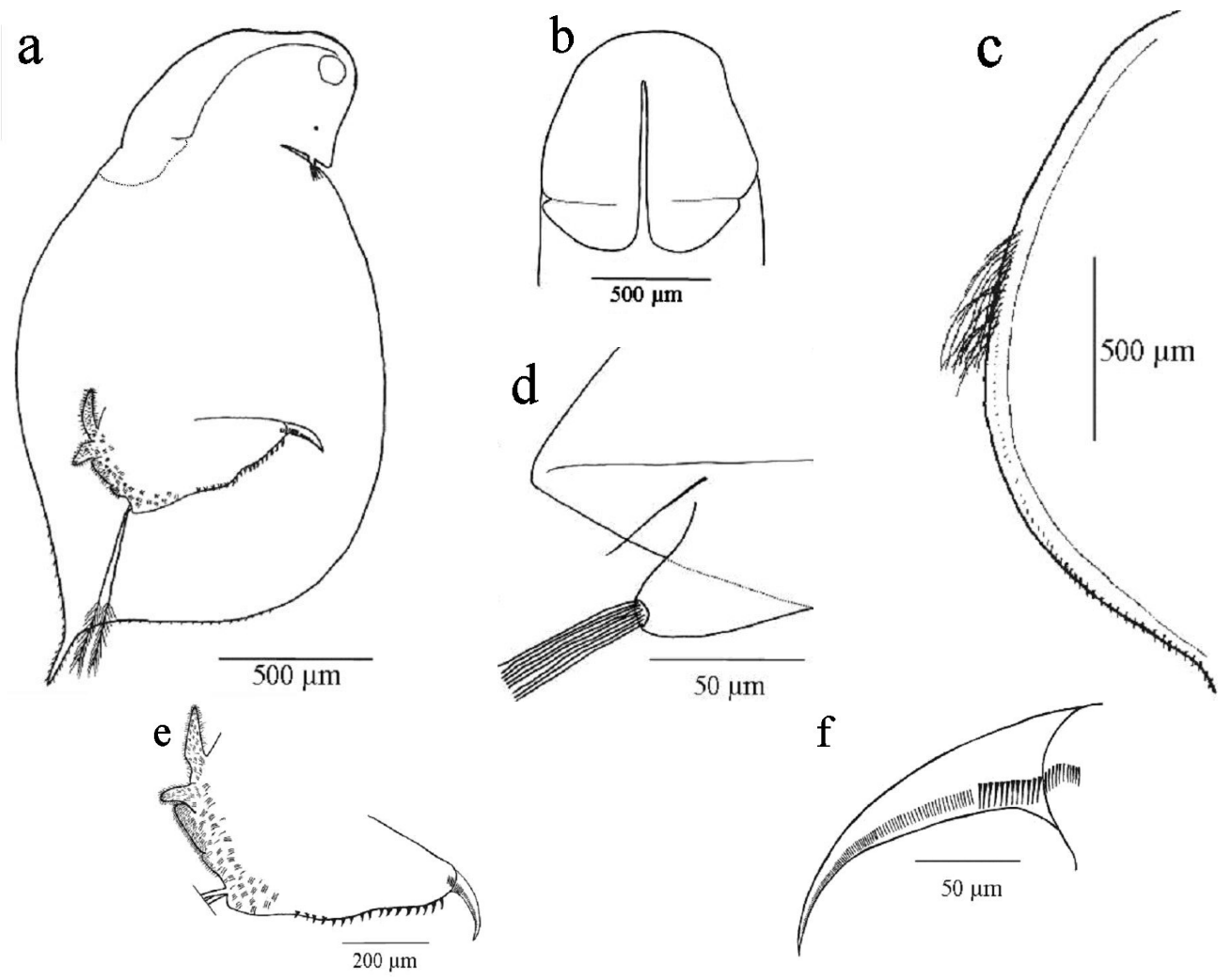

Fig. 2. Female Daphnia himalaya from the Khumbu Region. (a) Body in lateral view. (b) Dorsocephalic suture in dorsolateral view. (c) Inner ventral carapace margin. (d) Rostrum and antennule. (e) Postabdomen. (f) Postabdominal claws.

L29/F3/1, L29/F5/1-3). Individuals in alcohol samples reference numbers L9/10/10/94 and L29/29/9/97. Intersex: 1 individual mounted on slide, reference number L9/10/94/4 (photos reference numbers L9/MF1/1-5).

\subsubsection{Daphnia himalaya. Female}

Body length 2.0-2.5 mm. Carapace sub-oval in lateral view, with dark brown cuticular pigmentation all over (Fig. 2a). Carapace and headshield distinctly reticulate. Carapace spine present, very small in adults ( 0.1 times body length), larger in juveniles ( 0.2 times body length), spinulate. Head low and wide, depressed anteriorly, broadly rounded dorsally, ventral margin slightly concave near rostrum, defined dorsally by wellmarked depression, head length 0.2 times the body length. Eye well developed, projecting into antero-ventral corner, close to frontal margin of the head, giving slight bulge. Fornix well developed, rounded, extends into ocular region. Rostrum relatively prominent, though obtuse at the tip. Dorsocephalic suture of the headshield W-shaped (Fig. 2b). Carapace protruding along mid-dorsal line as medial strip between halves of headshield almost reaching top of head, such that the headshield has two distinct lateral wings, each posteriorly with a well-defined line. Juveniles with a medial hole anterior to the median groove (Manca et al. 1999). Dorsal keel absent. Ocellus present. Dorsal and ventral carapace margins posteriorly spinulate. Inner ventral margin of carapace centrally with few ( $c a$ 16) long, plumose, sub-marginal setae (Fig. 2c). Antennules close to rostrum tip (less than 2 aesthete-lengths), aesthetes equal to or slightly longer than base, tip of aesthetes equal to or exceeding rostrum tip, sensory seta subequal to length of base (Fig. 2d). Antennae spinulate (Fig. 3). Postabdominal processes $1>2>3=4$ (lengths in proportion $4: 2: 1: 1$ ), strongly setose. Postabdomen conical in shape, dorsal margin slightly embayed, anterior region strongly setose (Fig. 2e). Around 17 anal denticles subequal in size, separated from postabdominal claw by a small gap and extending over more than half the length of the dorsal margin. Postabdominal claw with three well developed combs, $2>1>3$ (Fig. 2f). Caudal setae long (0.3 times body length), bi-articulate, second article with plumose setation.

Ephippium elongate oval, black, with fine spinules on dorsal margin; two egg chambers oriented sub-parallel to the dorsal margin of the carapace (description from the individual described in Manca et al. 1994).

\subsubsection{Daphnia himalaya. Male}

Body length $1.3 \mathrm{~mm}$. Carapace sub-rectangular, darkly brown pigmented and distinctly reticulate, dorsal and ventral margins posteriorly spinulate (Fig. 4a). Antero-ventral margin densely covered with long setae. Carapace spine 0.2 times body length, spinulate. Head length 0.2 times body length, dorsally delineated by a 


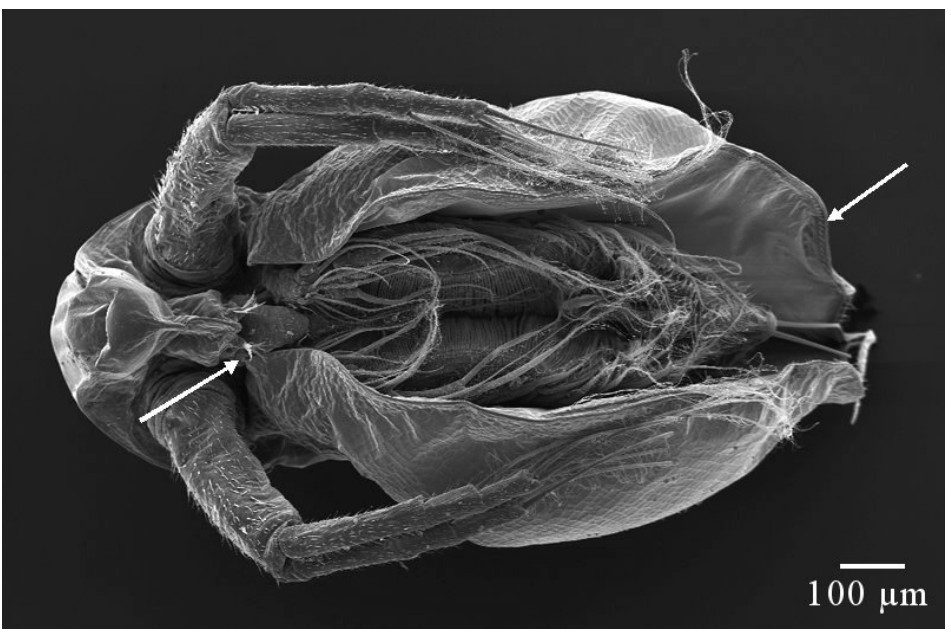

Fig. 3. SEM micrograph of female Daphnia himalaya from the Khumbu Region in ventral view clearly showing spinulation of antennae, reticulation of carapace, and setation and spinulation of inner ventral carapace margin. Arrows indicate the long aesthetes and carapace marginal spinulation.
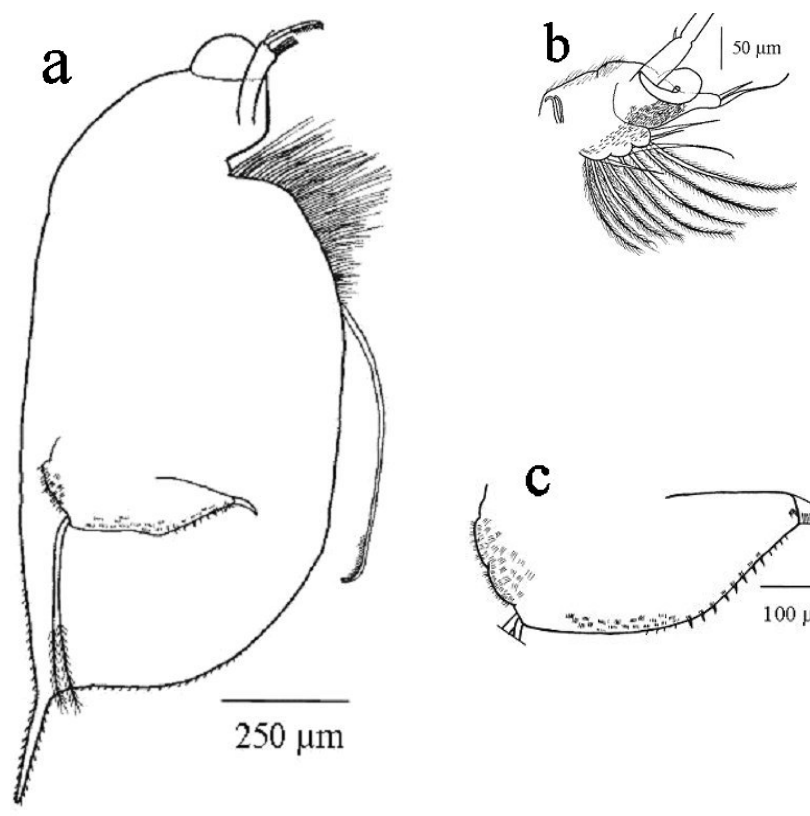

Fig. 4. Male Daphnia himalaya from the Khumbu Region. (a) Body in lateral view. (b) Trunk limb 1. (c) Postabdomen.

well-marked depression, ventral margin straight. Eye very prominent, located on the anterior margin of apex of head. Ocellus present. Rostrum very blunt. Antennule long (4.0 times width of base, 0.8 times length of head), very slightly spinulate, flagellum sub-equal to length of base, articles sub-equal in length, distal half of second article ventrally densely setose (Fig. 5a). Aesthetes 0.5 times length of flagellum. Sensory seta inserted distally, external in ventral view. Antennae spinulate, but less strongly than in female (Fig. 5b). Flagellum of P1 exopodite more than 0.5 body length, distally densely setose, spine of the exopodite short. Endopodite 4 with two long rami in proportion $2: 1$. Hook strongly curved, distally wide and with margins continuing sub-parallel almost to the apical portion (Figs. 4b, 5c). Limb strongly setose, especially on the distal ventral margin, but not medially (Fig. 4b). Postabdomen sub-triangular, dorsal margin not embayed, with $\mathrm{ca} 8$ anal denticles sub-equal in length and extending over less than half the length of the dorsal margin, separated from the postabdominal claw by 4 rows of strong spines running on the underside of the dorsal margin. Dorsal region of postabdomen between the anal denticles and the caudal setae with very short setae arranged in distinct groups of up to 6. Combs on postabdominal claw, and caudal setae, as for female. Postabdominal processes 1 and 4 hardly developed, 2 and 3 not well developed, sub-equal in length, strongly setose (Fig. 4c). 

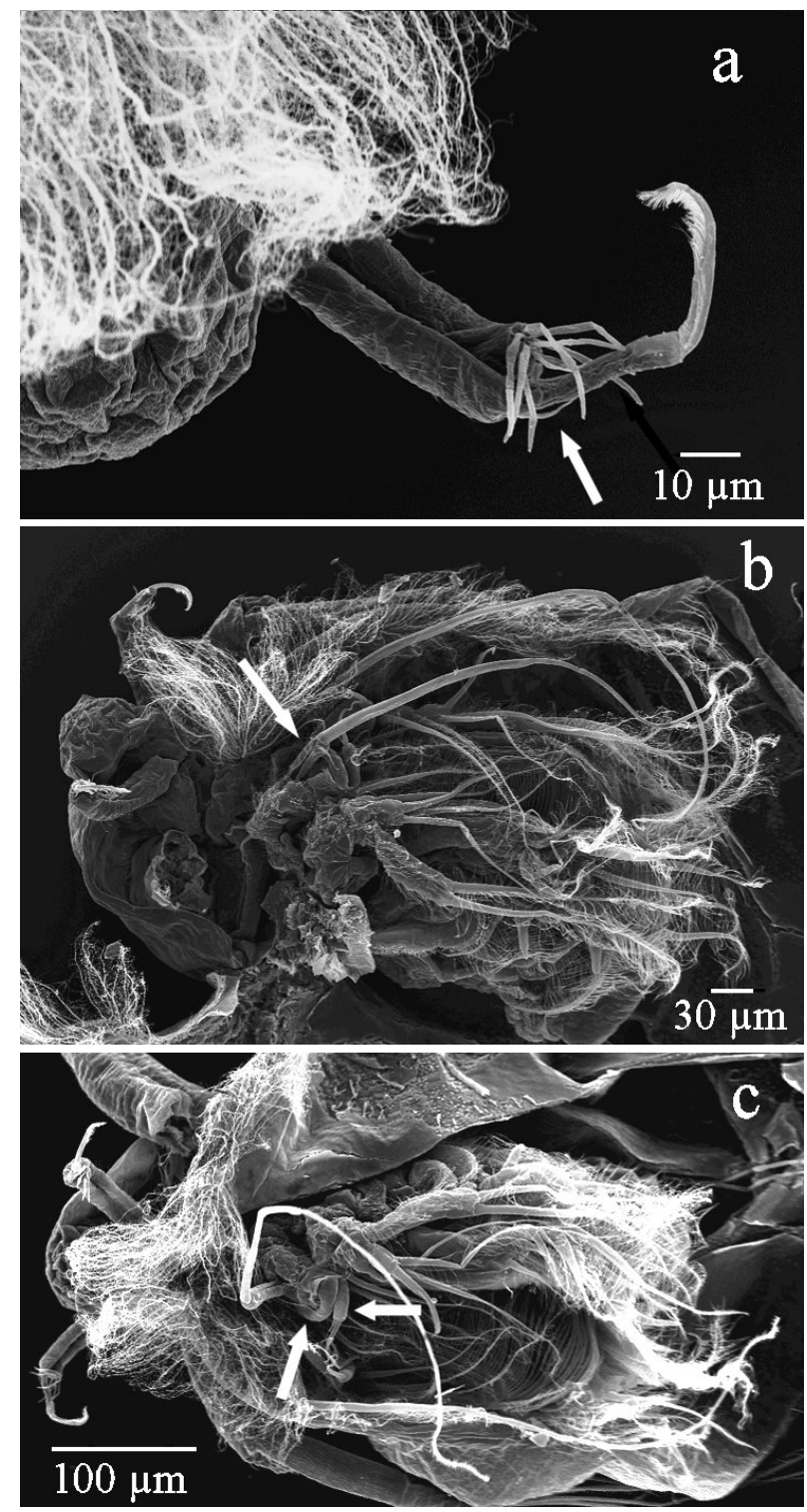

Fig. 5. SEM micrographs of male Daphnia himalaya from the Khumbu Region. (a) Antennule in ventral view, arrow indicating sensory seta. (b) Opened carapace to reveal trunk limbs, arrow indicating exopodite of P1. (c) Detail of P1, arrows indicating endopodite 4 and hook.

\subsection{Description of the sex intergrade specimen}

Body length $1.4 \mathrm{~mm}$ (Fig. 6a). Dorsal margin of carapace straight, as for male, ventral margin rounded, more similar to female. Carapace marginal spinulation and setation as for female. Carapace reticulated and with melanic pigmentation. Carapace spine 0.2 times body length, spinulate. Head length 0.2 times body length, ventral margin straight. Eye not giving rise to a bulge. Rostrum very blunt. One antennule exactly as for female, the other as for male, although with shorter base (0.5 times length of head), neither a flagellum nor aesthetes could be observed on the male antennule (Fig. 6b). Antennae spinulate. P1 developed as for male, but flagellum of exopodite was damaged and could thus not be measured. Postabdomen distinctly intermediate between male and female: dorsal margin slightly embayed, 11-13 anal denticles sub-equal in length and extending further than half the length of dorsal margin, separated from postabdominal claw by several strong spines. Combs on postabdominal claw as for female. Postabdominal processes 1 and 4 strongly reduced, 2 and 3 sub-equal in length but more strongly developed than in male, strongly setose (Fig. 6c).

\section{DISCUSSION AND CONCLUSIONS}

\subsection{Female}

The differences between female $D$. tibetana and $D$. fusca according to Benzie (2005) are summarized in table 1. Since that description of D. fusca includes the status of characters in drawings of specimens from the Khumbu Region, it is important to note that characters 2-6 derive from descriptions provided by Manuilova (1964) for D. pamirensis, and Gurney (1906) for $D$. fusca (or in the case of the dorsal ridge, inferred from these descriptions). For character 8 the range in number of anal denticles includes data for the Khumbu lakes specimens, as did the scoring for whether the anterior margin of the head was sinuate or not (character 6).

According to Benzie (2005) then, the distinction between female D. tibetana and D. fusca is based on $D$. tibetana having round fornices (1), a short rostrum (the tip of which is reached, or exceeded, by the antennular aesthetes) (2), combs on the postabdominal claws that are not strongly differentiated (3), no dorsal ridge (4), and two (the first and second) well developed postabdominal processes (5). In contrast, D. fusca has angled fornices (1), a long rostrum (the tip of which is not reached by the antennular aesthetes) (2), strongly differentiated combs on the postabdominal claw (3), a well developed dorsal ridge (4), and only one (the first) well developed postabdominal process (5). The anterior margin of the head is sinuate in some $D$. tibetana specimens, but considered not to be sinuate in any $D$. fusca specimens (6). Spinules on the posterior margin of the carapace are thought absent in $D$. tibetana while they are present in some, but not all, D. fusca individuals (7). The range in number of anal denticles overlaps in the two species (8).

With respect to the major characters differentiating the species, the Khumbu specimens described here differ strongly from D. fusca. Specifically, they have rounded rather than angled fornices, the rostrum is short and overlapped by the aesthetes rather than prominent and not overlapped by the aesthetes, two postabdominal processes are well developed, not just one, the anterior margin of the head is sinuate and the dorsal ridge is not well developed. The inferences made by Benzie (2005) from the sketches in Manca et al. (1994) for some of these characters were clearly in error, partly as a result of the incomplete nature of the drawings, as the samples described here came also from the same population. 

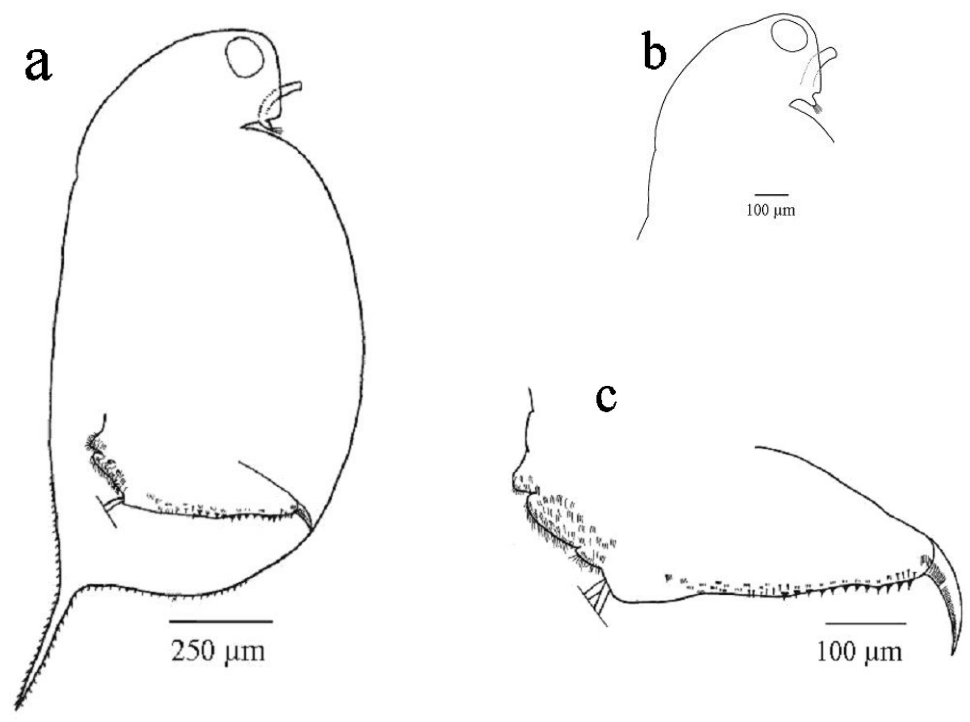

Fig. 6. Sex-intergrade of Daphnia himalaya. (a) Body in lateral view. (b) Head, clearly showing male and female antennules. (c) Postabdomen.

Tab. 1. List of the female diagnostic characters given by Benzie (2005) to distinguish between D. tibetana and D. fusca, and comparison to the species Daphnia himalaya described in the present paper.

\begin{tabular}{lccc}
\hline Character & $\begin{array}{c}\text { Daphnia tibetana } \\
(\text { sensu Benzie, 2005) }\end{array}$ & $\begin{array}{c}\text { Daphnia fusca } \\
(\text { sensu Benzie, 2005) }\end{array}$ & Daphnia himalaya \\
\hline 1. Fornices & Rounded & Angled & Rounded \\
2. Rostrum length & Short & Long & Short \\
3. Postabdominal claw & Combs not strongly & 3 distinct combs, 2>1>3 & 3 distinct combs, 2>1>3 \\
4. Dorsal ridge & Not well developed & Well developed & Not well developed \\
5. Postabdominal processes & 1 and 2 well developed 4:2:1:1 & Only 1 well developed 4:1.3:1:1 & 1 and 2 well developed 4:2:1:1 \\
6. Anterior margin of head & Sinuate in some specimens & Not sinuate & Sinuate \\
7. Posterior margin of carapace & Not spinulate & May be spinulate & Spinulate \\
8. Anal denticles & $10-20$ & Around 17 &
\end{tabular}

There is no evidence that the range in morphologies of these characters in the specimens from Khumbu overlaps those described for $D$. fusca, or that suggest more than one species was present in the population sampled. All of these characteristics are similar to descriptions of D. tibetana. However, in contrast, the postabdominal combs are differentiated in the Khumbu specimens and the carapace margins are spinulate. These data suggest a different mix of some characters among these montane populations (or overlap in the phenotypes of some characters) than explicitly described to date. However, the variation in degree of spinulation is consistent with the variation in this character observed in the past (Wagler 1936; Brehm \& Woltereck 1939). The setation of the ventral carapace margin closely resembles that reported for D. tibetana (Fig. 1363 in Benzie 2005, after Hann 1986), although the setation of D. fusca has not been described.

\subsection{Male}

The only data for male D. fusca is derived from drawings of the Khumbu populations in Manca et al. (1994). If the assignment of those populations to $D$. fusca was erroneous, as appears the case from more detailed descriptions of the females from those same populations, then no data on D. fusca males are known. The males from the Khumbu samples differ strongly from the description reported for D. tibetana males (Benzie 2005, after Chiang \& Du 1979). The most obvious diagnostic traits for those two types of males are as follows. In D. tibetana (sensu Benzie 2005) the carapace tail spine is absent (1), the body is sub-rectangular with the head almost as broad as the body (2), there are no spines on the posterior margins of the carapace (3), the antennule is short relative to the head (4), 
Tab. 2. List of male characters of D. tibetana (sensu Benzie 2005) and males of D. himalaya from the Khumbu population described in the present paper.

\begin{tabular}{lcc}
\hline Character & $\begin{array}{c}\text { Daphnia tibetana } \\
(\text { sensu Benzie, 2005 after Chiang and Du 1979) }\end{array}$ & Daphnia himalaya \\
\hline 1. Carapace tail spine & Absent & Present \\
2. Body and head & Head almost as broad as body & Head less broad than body \\
3. Spinules on posterior margin of carapace & Absent & Present \\
4. Antennule & Short relative to head & Long relative to head \\
5. Antenullar flagellum & Short $(<0.25$ base $)$ & Long $(0.8$ base $)$ \\
6. Postabdomen & Dewer than 10 & Dorsal margin straight \\
7. Anal denticles & Dround 8
\end{tabular}

the antennule has a short flagellum (0.25 length of base) (5), and the dorsal margin of postabdomen is slightly concave distally (6) (Tab. 2). In contrast, the males from Khumbu have a tail spine (1), the body is sub-rectangular with the head less broad than the body (2), there are spines on the posterior margins of the carapace (3), the antennule is long relative to the head (4), the antennule has a long flagellum (0.8 length of base) (5), and the dorsal margin of postabdomen is not concave distally (6). There are fewer than 10 short anal denticles in D. tibetana (7) and around 8 anal denticles (7) in the Khumbu material, the overlap meaning this character is not useful for distinguishing the species. It is clear then that the Khumbu populations are also not D. tibetana (sensu Benzie 2005, after Chiang \& Du 1979).

\subsection{The status of Ctenodaphnia species from the Himalayan and Tibet regions}

In their analysis of Ev-K2-CNR samples, Manca et al. (1994) also referred to specimens they collected from the Khumbu Region as D. tibetana, reporting drawings of female, ephippial female, as well as male specimens. Based on the head/carapace shields and the ephippium, Manca et al. (1999) considered the species belonged to the Ctenodaphnia subgenus, following Dybowski \& Grochowski (1895). Benzie (2005) suggested these specimens were $D$. fusca, based on inferences from drawings in Manca et al. (1994) that the present detailed descriptions of that population have demonstrated not to be correct. On balance the females do not resemble $D$. fusca, although one or two characters (postabdominal claw combs, and carapace spinulation) are more similar to this species than D. tibetana. However, the marked differences in the males of the Khumbu Region from those described for D. tibetana from Tibet (Chiang \& Du 1979), suggest the specimens are not $D$. tibetana either.

The males and females from Khumbu appear similar to material described recently from Tibet as $D$. tibetana (Zhao \& Wang 2005). The photographs given in Zhao \& Wang (2005) do not show a number of characters with clarity, nor are they clearly described in the text. Nevertheless, in the female, the rounded fornices, short rostrum, sinuate anterior margin of the head, and the occurrence of two well developed postabdominal processes are similar to the characters observed in the
Khumbu population. The two populations differ for the absence/presence of tail spines (lacking the former in adult individuals). The degree of spinulation of the carapace is not clear in the samples from Tibet and the number of postabdominal denticles (12-14) is lower than those of the Khumbu population (around 17).

In the male, the head appears to be less broad than the body, with a pronounced bulging eye, and has a long antennule relative to the head with a long bi-articulated flagellum of similar length to the base of the antennule. Differences are that the dorsal margin of the postabdomen appears sinuate to some degree, with less pronounced denticles, in the Zhao \& Wang (2005) sample.

The samples accessed by Zhao \& Wang (2005) were reared in captivity in artificial seawater from specimens obtained from Nam Tso, the second largest $\left(81,961 \mathrm{~km}^{2}\right.$ surface area) lake in Tibet, located $100 \mathrm{~km}$ NE from Lhasa (latitude $\mathrm{N} 30^{\circ} 42^{\prime} \mathrm{N}$ and longitude E $90^{\circ} 33^{\prime}$ ), at a high altitude (4720 m a.s.1.). It is a salty lake. In contrast, the Khumbu populations came from freshwater. It is clear that there are considerable similarities between the Khumbu and the Nam Tso samples. Some Daphnia (previously Daphniopsis) species have the ability to exist over a considerable range in salinities, but the marked difference in habitats together with some differences in morphology noted above suggest they are different taxa, and we name the samples from the Khumbu Region Daphnia himalaya.

Originally, D. tibetana was used as the type species for a new genus intermediate between Daphnia and Simocephalus, Daphniopsis (Sars 1903), based mainly on the lack of a carapace spine. Subsequently Daphniopsis has been subsumed in the Ctenodaphnia by Benzie (2005), because the characters used to define the genus were found not to be monophyletic, and were shared by at least some Daphnia species. In addition, the degree of spinulation of the carapace, and the length of the tail spine is variable in some Daphnia populations. This fact together with the occurrence of tail spines in the juveniles of some Ctenodaphnid (and some previous Daphniopsid) species that is then lost in the adults, suggest that using that character alone is inadequate to distinguish species let alone genera. For that reason, the distinction of two species as Daphniopsis tibetana and Daphnia tibetana solely on the basis of the presence or absence of tail spine (Zhao \& Wang 2005; 
Zhao et al. 2006) is suspect. These recent data from Tibet, together with the evidence of variation in spination and of postabdominal claw combs, in montane Ctenodaphnid populations suggest that further work is required to establish the limits of phenotypic variation of these characters at the population level, and in different habitats.

It is clear that more taxa are present in the region than has been recognised to date. There is at least one species found in the western region of the Himalayan range, in the Pamirs (D. fusca), that is still not well characterized, and for which no male or ephippial data are available. There are two species found in the eastern Himalayas and the Tibetan Plateau, at least both of which have been referred to as D. tibetana - one whose males have short antennae and which appear to have little or no spinules or tail spines (sensu Chiang \& Du 1979), found in far western China and Tibet, and one with a long antennule, greater spinulation and tail spines (sensu Zhao \& Wang 2005) described from Tibet. The species described by Zhao \& Wang (2005) will need to be renamed if Chiang \& $\mathrm{Du}$ (1979) described true specimens of $D$. tibetana in their earlier work.

It is possible that the Khumbu specimens are the same species as that described by Zhao \& Wang (2005), but this needs to be established by further sampling. In addition, the range of variation in Tibet and the Himalayas needs to be better described to distinguish clear boundaries between taxa, and genetic data would be of immense assistance in this regard.

\subsection{Remarks on intersex}

The occurrence of intersex males and females has long been known for different species of cladocerans (Frey 1965), including daphnids (Banta 1939), but has very rarely been documented in natural populations. Mitchell (2001) demonstrated the importance of environmental cues in sex induction in Daphnia magna, in particular an increased frequency of intersex individuals in response to temperature stress. She suggested that hormones may play a crucial role in normal male development, and therefore hypothesised that temperature stress has endocrine-disrupting effects. If intersex occurrence is indeed the result of endocrine disruption, a high frequency of intersex individuals would indicate the presence of endocrine-disrupting factors (such as hormone-mimicking pollutants, or stressful temperature changes) in natural populations, suggesting an additional tool for monitoring environmental changes, especially with regard to pollution in remote areas such as the Khumbu Region.

Sex intergrades are suggested to frequently be sterile (Mitchell 2001). A population with a high incidence of intersex might therefore produce a lower number of resting eggs, which would have implications for the population's ability to survive in any one lake. Only one sex intergrade was found in the samples examined for this taxonomic analysis. However, the Daphnia species re-described here was no longer found in samples from another lake of the Khumbu Region in which it had previously occurred continually for 3000 years as the only Daphnia species. The reasons for this are as yet unclear (Manca \& Comoli 2004) but subsequent research (Piscia, in preparation) revealed that the lake no longer contains a Daphnia egg-bank: all ephippia were found to be empty. The discovery of the intersex individual suggests it may be worthwhile to attempt to reconstruct the historical occurrence of sex intergrades in this lake, in order to determine whether intersex could have played a role in the extinction. Given the distinctly intermediate state of the postabdomen, which is a commonly found Daphnia subfossil, such a study is possible at least in principle, and would add to knowledge of the effects of environmental change in this region.

\section{ACKNOWLEDGEMENTS}

This study was carried out within the framework of the Ev-K2-CNR "Scientific and Technological Research in Himalaya and Karakorum" Project with support from the Ev-K2-CNR Committee and in collaboration with the Royal Nepal Academy of Science and Technology (RONAST) as foreseen by the Memorandum of Understanding between the Government of the Kingdom of Nepal and the Government of the Republic of Italy. The research conducted was also made possible thanks to contributions from the Italian National Research Council and the Italian Ministry of Foreign Affairs. We wish to thank Gabriele Tartari and Andrea Lami for collecting the samples. We are also very grateful to Pier Davide Pozzo, ISMAC, Biella, for his kind help and for granting us use of LEO SEM for the analyses of our specimens.

\section{REFERENCES}

Banta, A.M. 1939. Studies on the Physiology, Genetics, and Evolution of some Cladocera. Carnegie Institution of Washington, Washington D.C.: 285 pp.

Benzie, J.A.H. 2005. The Genus Daphnia (including Daphniopsis) (Anomopoda: Daphniidae). Backhuys Publishers, Leiden: $377 \mathrm{pp}$.

Brehm, V. \& R. Woltereck. 1939. Die Daphniden der YaleNorthindia-Expedition. Internat. Rev. ges. Hydrobiol., 39: $1-19$.

Chiang, S.C. \& N.S. Du. 1979. Fauna Sinica. Crustacea. Freshwater Cladocera. Science Press, Academica Sinica, Peking: 60-124.

Dybowski, B. \& M. Grochowski. 1895. Spis systematyczny Wioslarek (Cladocera) Krajowich. Kosmos, 20: 139-165.

Frey, D.G. 1965. Gynandromorphism in the chydorid Cladocera. Limnol. Oceanogr., 10: 103-114.

Guilizzoni, P., A. Lami, J.D. Smith, C. Belis, M. Bianchi, R. Bettinetti, A. Marchetto \& H. Muntau. 1998. Paleolimnological analysis of four himalayan lakes (Khumbu Valley, Nepal). In: R. Baudo, G. Tartari \& M. Munawar (Eds), Top of the World Environmental research: Mount Everest-Himalayan Ecosystem. Backhuys Publishers, Leyden: 189-217. 
Gurney, R. 1906. On some freshwater Entomostraca in the collection of the Indian Museum, Calcutta. J. Asiatic Soc. Bengal, 2: 273-281.

Hann, B.J. 1986. Revision of the genus Daphniopsis Sars, 1903 (Cladocera: Daphniidae) and a description of Daphniopsis chilensis, new species, from South America. J. Crustacean Biol., 6: 246-263.

Hutchinson, G.E. 1937. Limnological studies in Indian Tibet. Int. Rev. ges. Hydrobiol., 35: 134-177.

Löffler, H. 1968. Diaptomus (Arctodiaptomus) jurisovitchi nov. Spec. aus dem Khumbu-Gebiet (Nepal). Khumbu Himal., 3: 9-16.

Löffler, H. 1969. High altitude lakes in the Mt. Everest Region. Verh. int. Ver. Limnol., 17: 373-385.

Lami, A., G.A. Tartari, S. Musazzi, A. Marchetto, M. Manca A. Boggero, A.M. Nocentini, G. Morabito, G. Tartari, L. Guzzella, R. Bertoni, C. Callieri \& P. Guilizzoni. (2006). High altitude lakes: limnology and paleolimnology. - Developments in earth surface processes. In: A. da Polenza (Ed.), Mountains, Witnesses of global change. Elsevier: (submitted).

Manca, M. \& P. Comoli. 2004. Reconstructing long-term changes in Daphnia's body size from subfossil remains in sediments of a small lake in the Himalayas. J. Paleolimnol., 32: 95-107.

Manca, M., P. Cammarano \& T. Spagnuolo. 1994. Notes on Cladocera and Copepoda from high altitude lakes in the Mount Everest Region (Nepal). Hydrobiologia, 287: 225231 .

Received: September 2006

Accepted: November 2006
Manca, M., P. Comoli \& F. Margaritora. 1999. An unusual type of Daphnia head shields from plankton and sediments of Himalayan lakes. J. Limnol., 58: 29-32.

Manuilova, E.F. 1964. Cladocera of the fauna of the USSR. Zoological Institute of the USSR Academy of Sciences. Keys to the USSR fauna, 88: 1-329. (In Russian).

Mitchell, S.E. 2001. Intersex and male development in Daphnia magna. Hydrobiologia, 442: 145-156.

Rylov, W.M. 1930. Cladocera et Copepoda in Abhandlungen der Pamir-Expedition 1928. II. Zoologie: 105-133.

Sars, G.O. 1903. On the crustacean fauna of Central Asia. Part II. Cladocera. Ann. Mus. Zool. Acad. Imp. Sci. St. Petersbourg, 8: 157-194.

Tartari, G.A., G. Tartari \& R. Mosello. 1998. Water chemistry of high altitude lakes in the Khumbu and Imja Kola valleys (Nepalese Himalayas). Mem. Ist. ital. Idrobiol.: 57: 51-76.

Wagler, E. 1936. Die Systematik und geographische Verbreitung des Genus Daphnia O.F. Muller mit besonderer Berücksichtingung der südafrikanischen Arten. Arch. Hydrobiol., 30: 505-556.

Zhao, W. \& Q.H. Wang. 2005. The morphological redescription of Daphniopsis tibetana Sars (Crustacea: Cladocera: Daphnidae). Journal of Dalian Fisheries University, 20: 165-173.

Zhao, W., Y.Z. Huo \& J. Gao. 2006. Analysis and appraisement of nutrient compositions for Daphniopsis tibetana Sars. Journal of Fisheries Sciences China, 13: 446-451. 